\title{
Acquisition and completion of pregnant woman's medical booklet in four populational-based surveys
}

Tatiane Nogueira Gonzalez 1

https://orcid.org/0000-0002-9350-6152

Juraci Almeida Cesar 2

https://orcid.org/0000-0003-0864-0486

\footnotetext{
1 Programa de Pós-graduação em Ciências da Saúde. Faculdade de Medicina. Universidade Federal do Rio Grande. Campus da Saúde - Área Acadêmica Prof ${ }^{\mathfrak{0}}$ Newton Azavedo. Rua Visconde de Paranaguá, 102. CEP: 96.203-900. Rio Grande, RS, Brasil. E-mail: tnogueiragonzalez@gmail.com

2 Programa de Pós-graduação em Saúde Pública. Universidade Federal do Rio Grande. Rio Grande, RS, Brasil.
}

\begin{abstract}
Objectives: to measure the prevalence of acquiring and evaluating the level of completion of the pregnant women's medical booklet on the occasion of childbirth in Rio Grande, Brazil.

Methods: this is a cross-sectional study including all puerperals residing in this municipality in 2007, 2010, 2013 and 2016. The mothers were interviewed at the only two local maternities up to 48 hours after childbirth. The data from the pregnant woman's medical booklet were copied on a standard form. The chi-square test was used to compare proportions.

Results: 10,242 pregnant women were included in this study. Of these, $54.8 \%$ $(C 195 \%=53.8 \%-55.7 \%)$ had their pregnant woman's medical booklet with them at the time of admission. The completion pattern of the pregnant woman's medical booklet is divided into three groups, namely: with at least 95\%: date of the last consultation visit, maternal height and blood pressure verification, uterine height, cardio-fetal heart rate and the $R h$ factor; 85\% or more: date of the last menstruation, qualitative urine test, VDRL and HIV; and less than 30\%: performance of clinical breast examination and cytopathology of the uterine cervix. In the private sector, the acquisition of the pregnant woman's medical booklet was $41 \%$ lower than at the public sector (62\% vs. $44 \%)$.

Conclusions: the use of the pregnant woman's medical booklet and its completion were lower than expected on several items. Local managers need to work together with the health professionals and these health professionals should work with the mothers to promote the full use of this essential document for the maternal and child's health.
\end{abstract}

Key words Prenatal care, Medical records, Health evaluation

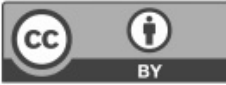




\section{Introduction}

The pregnant women's medical booklet are the most complete and easily accessible document there is for pregnancy. It is a vital instrument for registering all the procedures and examinations performed, as well as to monitor the development of the pregnancy. This is important for the maternal and the child's wellbeing and for the health professionals in decisionmaking during the pregnancy.

In 1988, the Cartão da Gestante (Pregnant woman's medical card) was created and the pregnant woman's medical card underwent several modifications. The first version of the card had information about maternal demographic characteristics, reproductive history, some clinical and laboratory tests performed and pre-existing morbidities. 1 The most relevant changes occurred in 2015 when the pregnant woman's medical card was submitted to a significant reformulation, it was called the Caderneta da Gestante (Pregnant woman's booklet). At that time, information on healthy pregnancy, baby development, breastfeeding and women's rights during pregnancy were included in the booklet. ${ }^{2}$ In 2016, the new version of the booklet included information on prevention and protection against dengue, as well as syphilis treatment and prevention. 3

The Ministry of Health recommends that this important instrument for prenatal care should always remain with the pregnant woman, and it is the health professional's responsibility to register all the procedures that the pregnant woman performed, in order to ensure the continuity on care and the flow of information among the services. 4

Since its inception, some studies have evaluated the acquisition of the pregnant woman's medical booklet at the parturient's admission at the maternity. This acquisition of the booklet ranged from $72 \%$ to 99\%.5-9 Studies on its completion are still very scarce. In Recife city (PE), ${ }^{7}$ only $36 \%$ of the booklets contained the registration of anti-HIV serology, while in Vitória city (ES), 8 97\% of them registered the information in their booklet .

In general, studies addressing this issue are restricted to assess the demand in specific services and are, therefore, not representative for the population. 10-13 This hinders the establishment of measures and actions, especially at municipality level because the recommendations may not apply to all existing services.

This study evaluates the acquisition and completion of the pregnant woman's medical booklet among the parturients living at municipality level of Rio Grande (RS), Brazil, in a four populational- based surveys.

\section{Methods}

This article was elaborated from the data on perinatal studies in Rio Grande (RS), Brazil. This municipality is located in the South coastal range, at about $300 \mathrm{~km}$ from Porto Alegre and $250 \mathrm{~km}$ from the border of Uruguay. In 2016, there were about 213,000 inhabitants, $95 \%$ of them resided in urban areas. The health service consisted of two hospitals, Santa Casa de Misericórdia and the Hospital Universitário da Universidade Federal do Rio Grande (FURG) (University Hospital), exclusive to the Sistema Único de Saúde (National Health Service), both with maternities, three medical specialized outpatient clinics and 32 primary health units.

These surveys aimed to evaluate the gestational and childbirth care received by all the parturients living in the urban and rural areas in this municipality from Jan. 01st to Dec.12th in 2007, 2010, 2013 and 2016. In being included in this study, the newborns should have reached a weight equal to or greater than 500 grams or were at least 20 weeks of gestational age.

The cross-sectional design was used, and the mothers were interviewed only once at the maternity up to 48 hours after the childbirth. 14 The sample size calculation was performed posteriori. Considering the 10,242 parturients included in these studies, the prevalence of the acquisition of the pregnant woman's medical booklet at the occasion of the childbirth, it was $50 \%$ and at a confidence level of $95 \%$, it was possible to work with an error margin of 1 p.p. This calculation was performed on Epi Info software, version 7.2.10.15

The pregnant woman's medical booklet was considered as any other document at the public or private sectors, in which the pregnant woman had to have the medical booklet in other to be admitted at the hospital and provided the data on the procedures and examinations performed during prenatal care.

All the information shown here were obtained through a direct application of a single, standardized, pre-coded questionnaire with a predominance of closed-ended questions, which was divided into blocks containing information on demographic, socioeconomic, occupational, reproductive characteristics, gestational morbidity, life habits and maternal behavior, as well as care received during prenatal care and childbirth All the information from the pregnant woman's medical booklet were copied to a standard form. 
Four interviewers were trained for each of the surveys. Each of them in the pilot study was performed in the same maternities in the month preceding the onset of the data collection. The search for the parturients was performed from the birth registration book at each maternity and through visits in the wards. All the mothers living in the municipality of Rio Grande were invited to participate in this study.

In 2007, 2010, and 2013 surveys, the interviews were conducted by using printed questionnaires. This step was performed by using EpiData Association software, Odense, Denmark (EpiData 3.1). ${ }^{16}$ In the 2016 survey, tablets were used for the interviews; the information was downloaded at Universidade Federal do Rio Grande (FURG) server through the Research Electronic Data Capture (REDCap) 17 for immediate verification and correction of possible inconsistencies.

The analysis were performed by using the STATA version 12.1 program (StataCorp LP, College Station, USA). 18 The prevalence of the outcome and the frequency of completion of the information registered in the pregnant woman's medical booklet among the surveys were compared by using the chisquare test with Yates' correction. 19

The survey research protocols were approved by the Ethics Committee in the Health Research Area at Universidade Federal do Rio Grande (FURG) as follows: 2007 (process file number: 05369/2006), 2010 (process file number: 06258/2009), 2013 (process file number: 02623/2012) and 2016 (process file number: 0030-2015).

\section{Results}

Data from the Sistema de Informações sobre Nascidos Vivos (Sinasc) (Information System on Live Births) revealed that 10,626 mothers residing in the municipality had a child in one of the two local maternities in 2007, 2010, 2013 and 2016. Of this total, 10,242 of them (or $96.4 \%$ of the total) were possible to be interviewed.

Table 1 shows that $18 \%$ of the puerperals were adolescents, $68 \%$ were white, $58 \%$ had at least concluded high school, $36 \%$ had a family income of at least three monthly minimum wages and $42 \%$ were employed during the gestational period. A little more than $40 \%$ were primiparous, $37 \%$ mentioned they had planned to get pregnant, $97 \%$ had some prenatal consultations, $78 \%$ of them started the prenatal in the first trimester and $82 \%$ completed at least six consultations during the gestational period. A little more than half (55\%) performed prenatal care at the public service, $35 \%$ at the Unidades Básicas de Saúde (UBS) (Primary Health Units) and $20 \%$ at the outpatient clinics.

In Figure 1 it is possible to verify the acquisition of the pregnant woman's medical booklet in the studied period among all the mothers was 55\% (CI95\% $=54 \%-56 \%)$, ranging from $51 \%$ in 2010 to $59 \%$ in 2013 . In 2016, this acquisition was $41 \%$ higher among the puerperals assisted at the public service than at the private sector (62\% versus $44 \%$ ).

Table 2 shows the almost universal completion of the pregnant woman's medical booklet regarding the date and weight in the first and last prenatal care consultation, at least once the blood pressure was verified, uterine height, $\mathrm{Rh}$ factor, and the performance of pelvic ultrasound. The completion of the last menstruation occurred in $78 \%$ of the medical booklets, weight before getting pregnant in $65 \%$ while fasting of glucose, qualitative urine test, and Venereal Disease Research Laboratory (VDRL) and human immunodeficiency virus (HIV) testing were observed by about $90 \%$ of them. The lowest registration frequencies occurred for clinical breast examination and cytopathology uterine cervix at $17 \%$ and $26 \%$, respectively. Finally, in the same table shows that there was a significant worsening in the completion of the date of the last menstruation, clinical breast examination, cytopathology uterine cervix, weight before getting pregnant, maternal height and $\mathrm{Rh}$ factor, and substantial improvement in the performance of glycemic tests, hemoglobin, anti-HIV, serology for syphilis, qualitative urine test, date of the first ultrasound and gestational age in this examination.

\section{Discussion}

In Rio Grande, the acquisition of pregnant woman's medical booklet at the occasion of childbirth, albeit significantly higher among puerperals who underwent prenatal care at the public sector, was low and has been declining. Its completion is variable, close to universalization of some items, while for others were far below than expected.

In Pelotas, a nearby city, the prevalence of acquisition was $83 \%,{ }^{6}$ while in a national hospital-based survey, it was $72 \% .20$ As there was no lack of the pregnant woman's medical booklet between 2007 and 2016 in Rio Grande, nor a substantial increase in the number of pregnant women who started prenatal care was from $97 \%$ to $99 \%$ in the same period, it is possible to suggest that the acquisition of this document has been undervalued, especially at the private sector. In this sector, the acquisition of the pregnant 
Table 1

Characteristics of puerperals residents at the municipality level during the four years of the study. Rio Grande, RS, Brazil, 2007, 2010, 2013 and 2016.

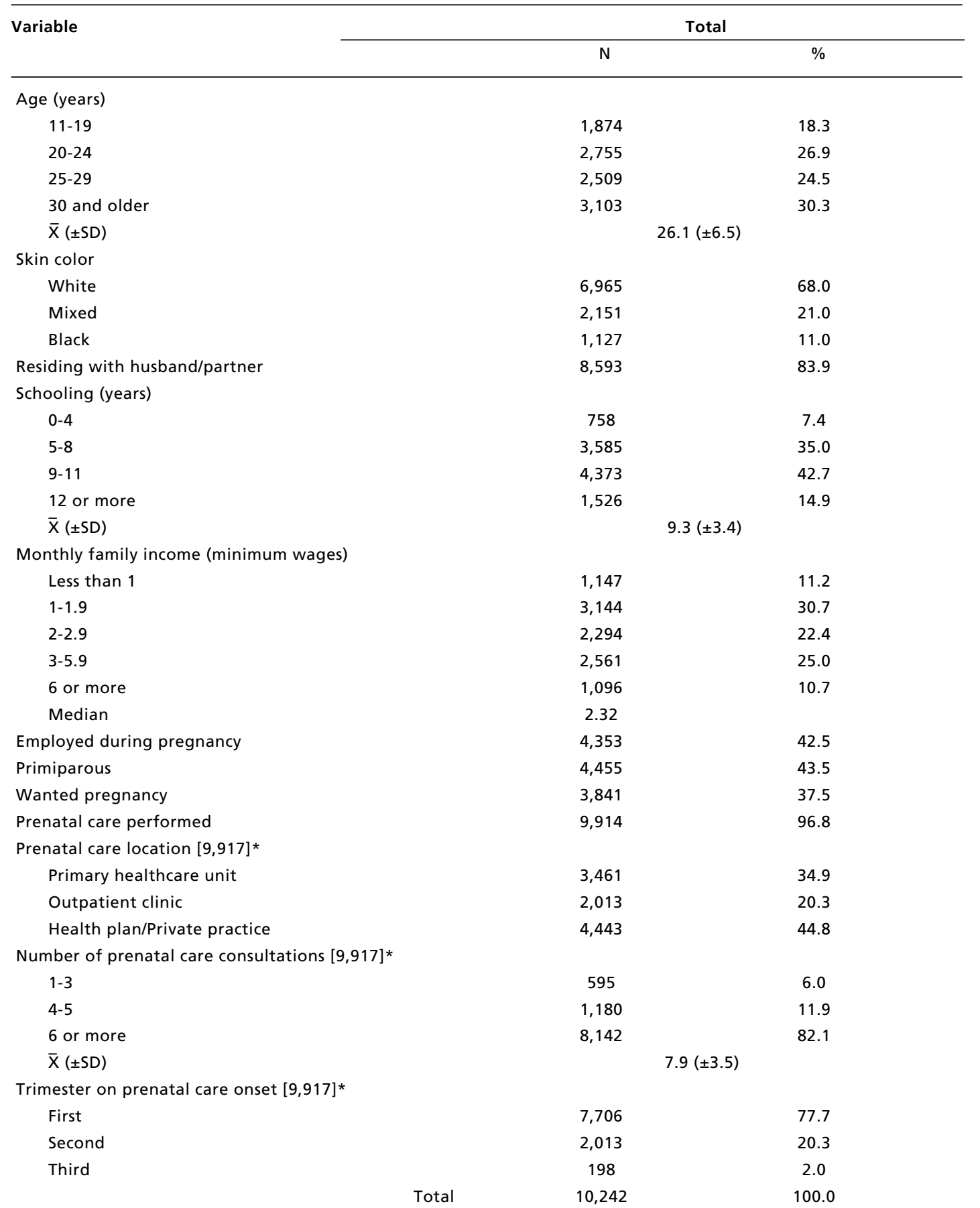

* Only among those who performed at least one prenatal consultation. 
Time evolution of the acquisition of the pregnant woman's medical booklet during the four years of the study. Rio Grande, RS, Brazil. 2007, 2010, 2013 and 2016. ( $N=9,917)$.

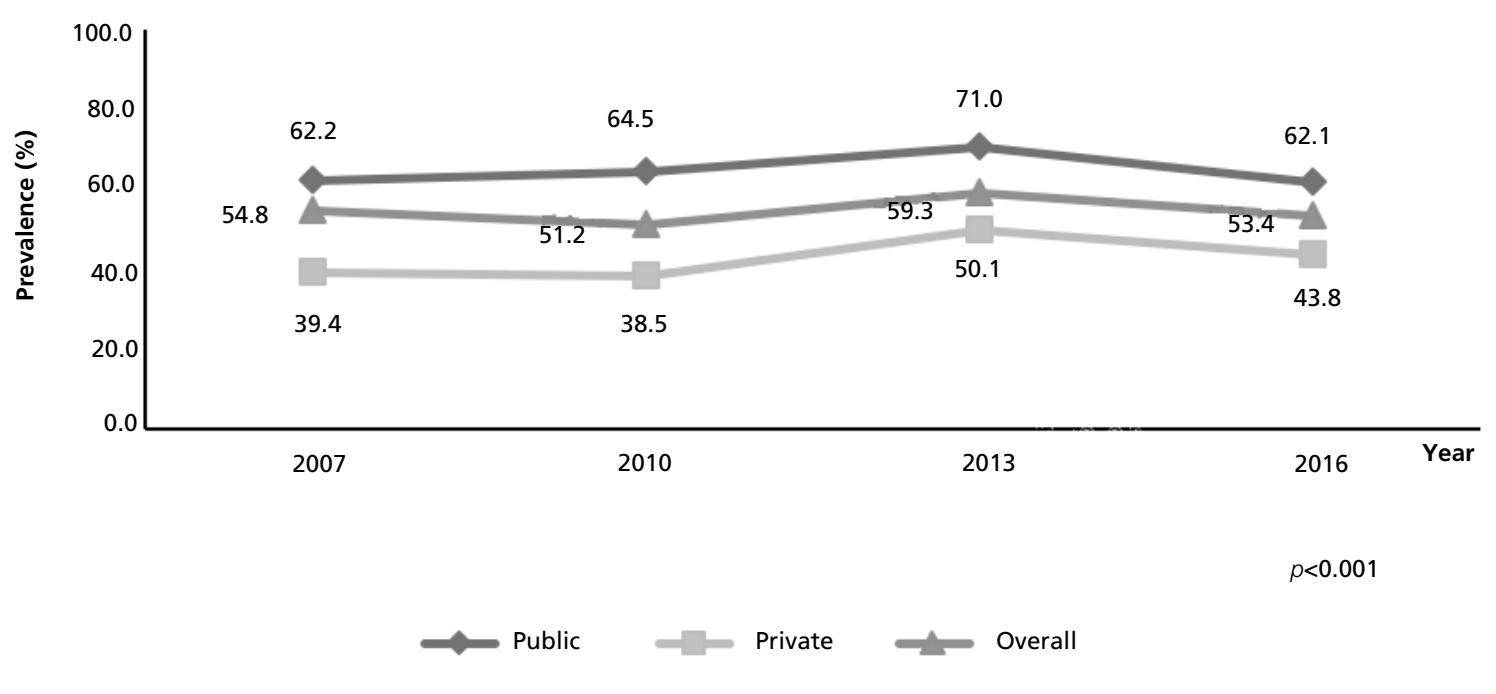

woman's medical booklet was always lower than at the public sector, ranging from $41 \%$ to $68 \%$ (Figure $1)$.

Regarding to the pregnant woman's medical booklet completion, different patterns were observed. This mosaic of findings reinforces that this instrument has been working poorly. This may be due to the non-portability of the pregnant woman's medical booklet by mothers and the non-registration of the procedures performed by the health professionals. A similar finding was found concerning the Caderneta de Saúde da Criança (Child's Health booklet). ${ }^{21}$

The comparison of the results of this study was impaired by the fact that other studies addressing the topic had mentioned only the variables that had higher or lower completion rates were in Juiz de Fora (MG), ${ }^{7}$ Recife (PE), 8 Vitória (ES) ${ }^{10}$ and Ponta Grossa (PR). ${ }^{22}$ In all of them, the referred rates were similar to those observed in Rio Grande, suggesting that the lack of standardized completion also occurred in other locations.

Other authors who have evaluated the pregnant woman's medical booklet completion suggest that there is a greater appreciation by both the mothers and the health professionals regarding laboratory tests, in detriment of prenatal clinical exams. 10,23,24 This was not confirmed systematically in this study. What seems to occur is that all the examination that took a little more time, especially the physician's, which it was, in fact, lower than expected, both for the laboratory and for the clinical,11,21,24-27 as for the qualitative urine test, VDRL and clinical breast examination and cytopathology uterine cervix.7,13 It should be noted that the latter is not always necessary, since women may have performed it in less than three years, with a negative result, which would discharge its performance in a current gestation. Besides this, it is necessary to take into account the resistance of some mothers in the performance of exams such as the cytopathology test itself and the breast examination during the prenatal period. 28

By interpreting the results of this time series, it is necessary to take in consideration some limitations, such as the changes in the information collected in different booklets facilitated by the Ministry of Health over these years that prevent the comparison of the evolution of some indicators over the period; the lack of standardization of different booklets available, especially those provided by the private sector that are restricted to a smaller number of items. It should also be pointed out that in the first surveys a few registrations were transcribed to a standard form. In 2016, it was decided to copy all the contents of the pregnant woman's medical booklet to the standard form.

This study showed that the acquisition of the pregnant woman's medical booketl is low, and there is a necessity to encourage the portability of this document at every medical consultation during the 
Table 2

Acquisition of the pregnant woman's medical booklet according to the sur

\begin{tabular}{|c|c|c|c|c|c|c|c|c|c|c|c|c|c|}
\hline \multirow[t]{2}{*}{ Variable } & \multicolumn{2}{|c|}{$\begin{array}{c}2007 \\
(n=1,394)(\%)\end{array}$} & \multirow[t]{2}{*}{$p$} & \multicolumn{2}{|c|}{$\begin{array}{c}2010 \\
(n=1,216)(\%)\end{array}$} & \multirow[t]{2}{*}{$p$} & \multicolumn{2}{|c|}{$\begin{array}{c}2013 \\
(n=1,573)(\%)\end{array}$} & \multirow[t]{2}{*}{$p$} & \multicolumn{2}{|c|}{$\begin{array}{c}2016 \\
(n=1,426)(\%)\end{array}$} & \multirow[t]{2}{*}{$p$} & \multirow[t]{2}{*}{ Total (\%) } \\
\hline & Publ. & Priv. & & Publ. & Priv. & & Publ. & Priv. & & Publ. & Priv. & & \\
\hline Date of last menstruation & 84.4 & 87.6 & 0.238 & 86.3 & 82.6 & 0.094 & 84.7 & 65.8 & $<0.001$ & 84.4 & 38.7 & $<0.001$ & 78.6 \\
\hline Date of the first prenatal care consultation & 98.6 & 99.5 & 0.259 & 99.9 & 99.9 & 0.510 & 99.8 & 99.2 & 0.084 & 99.7 & 99.8 & 0.681 & 99.5 \\
\hline Date of the last prenatal care consultation & 97.5 & 99.9 & 0.022 & 99.4 & 99.2 & 0.655 & 98.8 & 99.2 & 0.495 & 99.6 & 99.4 & 0.653 & 98.9 \\
\hline Maternal weight & - & - & - & 99.6 & 99.2 & 0.291 & 99.9 & 99.5 & 0.146 & 99.6 & 100 & 0.144 & 99.7 \\
\hline Blood pressure & - & - & - & 97.3 & 99.2 & 0.036 & 97.8 & 97.3 & 0.507 & 99.6 & 99.4 & 0.653 & 98.3 \\
\hline Uterine height & - & - & - & 99.3 & 97.8 & 0.028 & 98.8 & 95.3 & $<0.001$ & 99.1 & 94.3 & $<0.001$ & 97.9 \\
\hline Fetal heart rate & - & - & - & 99.4 & 98.1 & 0.033 & 98.5 & 97.4 & 0.119 & 98.1 & 99.0 & 0.185 & 98.5 \\
\hline Clinical breast examination & - & - & - & 32.4 & 34.0 & 0.600 & 9.7 & 12.9 & 0.048 & 6.4 & 15.9 & $<0.001$ & 16.9 \\
\hline Cytopathology uterine cervix & - & - & - & 34.2 & 32.9 & 0.655 & 43.3 & 32.5 & $<0.001$ & 6.6 & 5.0 & 0.251 & 26.4 \\
\hline Weight before getting pregnant & - & - & - & 68.3 & 53.8 & $<0.001$ & 73.8 & 72.8 & 0.665 & 68.6 & 35.5 & $<0.001$ & 65.1 \\
\hline Weight at the first prenatal care consultation & 94.3 & 87.6 & $<0.001$ & 99.2 & 98.4 & 0.210 & 99.9 & 99.5 & 0.146 & 99.8 & 98.2 & 0.001 & 97.8 \\
\hline Weight at the last prenatal care consultation & 91.1 & 85.2 & 0.007 & 98.0 & 95.9 & 0.038 & 98.5 & 99.0 & 0.380 & 98.6 & 97.8 & 0.252 & 96.2 \\
\hline Fasting of glycemia & - & - & - & 88.3 & 83.7 & 0.028 & 87.9 & 90.8 & 0.069 & 89.2 & 95.6 & $<0.001$ & 89.2 \\
\hline Qualitative urine test & - & - & - & 86.0 & 85.3 & 0.769 & 85.4 & 94.4 & $<0.001$ & 88.5 & 92.3 & 0.022 & 88.3 \\
\hline VDRL or rapid test & - & - & - & 83.7 & 86.7 & 0.189 & 93.6 & 94.5 & 0.440 & 94.0 & 86.9 & $<0.001$ & 90.4 \\
\hline Anti-HIV & - & - & - & 88.3 & 89.7 & 0.494 & 91.1 & 93.6 & 0.072 & 95.4 & 89.9 & $<0.001$ & 91.6 \\
\hline First hemoglobin & - & - & - & 74.3 & 70.6 & 0.188 & 83.8 & 89.2 & 0.002 & 85.4 & 95.4 & $<0.001$ & 83.2 \\
\hline Second hemoglobin & - & - & - & 36.2 & 52.2 & $<0.001$ & 47.9 & 64.3 & $<0.001$ & 50.2 & 78.6 & $<0.001$ & 52.5 \\
\hline First fasting of glycemia & - & - & - & 87.7 & 81.5 & 0.004 & 86.9 & 89.2 & 0.160 & 89.5 & 95.2 & $<0.001$ & 88.5 \\
\hline Second fasting of glycemia & - & - & - & 36.3 & 53.8 & $<0.001$ & 49.4 & 60.6 & $<0.001$ & 51.5 & 78.2 & $<0.001$ & 52.7 \\
\hline $\mathrm{Rh}$ factor & - & - & - & 96.7 & 98.6 & 0.055 & 100 & 100 & 0.786 & 88.9 & 90.3 & 0.414 & 95.6 \\
\hline Maternal height & 85.2 & 96.2 & $<0.001$ & 83.7 & 87.0 & 0.151 & 92.1 & 90.7 & 0.316 & 66.3 & 22.2 & $<0.001$ & 78.6 \\
\hline Pelvic ultrasound & 94.5 & 98.6 & 0.012 & 92.6 & 97.5 & 0.001 & 95.1 & 98.2 & 0.001 & 92.8 & 97.4 & $<0.001$ & 95.0 \\
\hline Date of the first pelvic ultrasound & 88.9 & 97.1 & $<0.001$ & 89.1 & 94.6 & 0.003 & 93.6 & 95.8 & 0.058 & 91.9 & 96.2 & 0.002 & 92.3 \\
\hline Gestational age at the first pelvic ultrasound & 88.3 & 95.7 & 0.001 & 87.4 & 94.0 & $<0.001$ & 93.4 & 95.5 & 0.078 & 91.7 & 95.8 & 0.004 & 91.7 \\
\hline Total & 78.2 & 21.8 & $<0.001$ & 57.9 & 42.1 & $<0.001$ & 51.9 & 48.1 & $<0.001$ & 57.0 & 43.0 & $<0.001$ & \\
\hline
\end{tabular}

VDRL= Venereal Disease Research Laboratory; HIV= Human Immunodeficiency Virus. 
gestational period, and especially at the occasion of the childbirth. It also revealed that it is necessary to reinforce with the health professionals the obligation to complete all the information contained in the pregnant woman's medical booklet. This can optimize the provision of a more appropriate care for both the pregnant woman and the newborn, which contributes to reduce mother and child's morbimortality.

\section{Authors' Contribution}

Gonzalez TN performed the data analysis and interpretation, drafting and reviewed the final version of

\section{References}

1. Brasil. Ministério da Saúde, Assistência pré-natal. Divisão Nacional de Saúde Materno-Infantil, Secretaria Nacional de Programas Especiais de Saúde. Brasília: 1988.

2. Brasil. Ministério da Saúde. Caderneta da Gestante. Brasília: 2014. Disponível em: http://189.28.128.100/dab/ docs/portaldab/documentos/caderneta_gestan te.pdf

3. Brasil. Ministério da Saúde. Caderneta da Gestante. Brasília, DF; 2016. Disponível em: http://portalarquivos2. saude.gov.br/images/pdf/2016/marco/01/Caderneta-GestInternet.pdf

4. Brasil. Ministério da Saúde. Atenção ao pré-natal de baixo risco. Secretaria de Atenção à Saúde. Departamento de Atenção Básica. Brasília, DF; 2013.

5. Viellas EF, Domingues RMSM, Dias MAB, Gama SGNd, Theme-Filha MM, Costa JV, Bastos MH Leal MC. Assistência pré-natal no Brasil. Cad Saúde Pública. 2014; 30 (Supl.1): S85-S100.

6. Dode MASO, Santos IS. Validade do auto-relato de diabete mellitus gestacional no pós-parto imediato. Cad Saúde Pública. 2009; 25: 251-8.

7. Carvalho VCP, Araújo TVB. Adequação da assistência prénatal em gestantes atendidas em dois hospitais de referência para gravidez de alto risco do Sistema Único de Saúde, na cidade de Recife, Estado de Pernambuco. Rev Bras Saúde Mater Infant. 2007; 7: 309-17.

8. Santos Neto ET, Leal MC, Oliveira AE, Zandonade E, Gama SGN. Concordância entre informações do Cartão da Gestante e da memória materna sobre assistência pré-natal. Cad Saúde Pública. 2012 ;28: 256-66.

9. Domingues RMSM, Hartz ZMA, Dias MAB, Leal MC. Avaliação da adequação da assistência pré-natal na rede SUS do Município do Rio de Janeiro, Brasil. Cad Saúde Pública. 2012; 28: 425-37.

10. Paris GF, Pelloso SM, Martins PM. Qualidade da assistência pré-natal nos serviços públicos e privados. Rev Bras Ginecol Obstet. 2013; 35: 447-52.

11. Silva MB, Monteiro PS. Adequação do pré-natal em gestantes atendidas na Estratégia de Saúde da Família em Palmas-TO, 2009. Com Ciências Saúde. 2010; 21 (1): 21 30 . the article. Cesar JA outlined the study, participated in the data interpretation, drafting and reviewed the final version of the article. Both authors approved the final version of the manuscript.

12. Polgliane RBS, Leal MC, Amorim MHC, Zandonade E, Santos Neto ET. Adequação do processo de assistência prénatal segundo critérios do Programa de Humanização do Pré-natal e Nascimento e da Organização Mundial de Saúde. Ciênc Saúde Coletiva. 2014; 19 (7): 1999-2010.

13. Anversa ETR, Bastos GAN, Nunes LN, Dal Pizzol TS. Qualidade do processo da assistência pré-natal: unidades básicas de saúde e unidades de Estratégia Saúde da Família em município no Sul do Brasil. Cad. Saúde Pública. 2012; 28 (4): 789-800.

14. Silva IS. Cancer epidemiology: principles and methods. Lyon: World Health Organization \& International Agency for Research on Cancer; 1999.

15. Dean AG, Dean JA, Coulombier D, Brendel KA, Smith DC, Burton AH, et al. Epi-Info, Version 6: A Word Processing, Database, and Statistics Program for Epidemiology on Microcomputers. Atlanta: Centers of Disease Control and Prevention; 2002.

16. Lauritsen JM (Ed.EpiData Data Entry, Data Management and basic Statistical Analysis System [Internet]. Odense Denmark: EpiData Association; 2000-2008. Available from: http://www.epidata.dk

17. Harris PA, Taylor R, Thielke R, Payne J, Gonzalez N, Conde JG. Research electronic data capture (REDCap). A metadata-driven methodology and workflow process for providing translational research informatics support. J Biomed Inform. 2009; 42: 377-81.

18. Stata Corp. Stata statistical software: release 11.2. College Station: Stata Corporation; 2011.

19. Kirkwood BR, Sterne JAC. Essentials of medical statistics 2 ed. London: Blackwell Science Ltd; 2003.

20. Domingues RMSM, Viellas EF, Dias MAB, Torres JA, Theme-Filha MM, Gama SGN, Leal MC. Adequação da assistência pré-natal segundo as características maternas no Brasil. Rev Panam Salud Publica. 2015; 37 (3): 140-7.

21. Amorim LP, Senna MIB, Gomes VE, Amaral JHL, Vasconcelos M, Silva AG, Lucas SD, Ferreira RC. Preenchimento da Caderneta de Saúde da Criança nos serviços de saúde em Belo Horizonte, Minas Gerais, Brasil. Epidemiol Serv. Saúde. 2018: 27 (1): e201701116. 
22. Coutinho T, Monteiro MFG, Sayd JD, Teixeira MTB, Coutinho CM, Coutinho LM. Monitoramento do processo de assistência pré-natal entre as usuárias do Sistema Único de Saúde em município do Sudeste brasileiro. Rev Bras Ginecol Obstet. 2010; 32: 563-9.

23. Barreto FDFP, Albuquerque RM. Discrepâncias entre o informe verbal e os registros no cartão da gestante, um instrumento negligenciado. Rev Bras Ginecol Obstet. 2012; 34: 259-267.

24. Trevisan MR, Lorenzi DRS, Araújo NM, Ésber K. Perfil da assistência pré-natal entre usuárias do sistema único de saúde em Caxias do Sul. Rev Bras Ginecol Obstet. 2002; 24: 293-9.

25. Martinelli KG, Santos Neto ET, Gama SGN, Oliveira AE. Adequação do processo da assistência pré-natal segundo os critérios do Programa de Humanização do Pré-natal e Nascimento e Rede Cegonha. Rev Bras Ginecol Obstet. 2014; 36 (2): 56-64.

Received on August 22, 2018

Final version presented on 26, 2019

Approved on April 30, 2019
26. Vettore MV, Dias M, Vettore MV, Leal MC. Avaliação da qualidade da atenção pré-natal dentre gestantes com e sem história de prematuridade no Sistema Único de Saúde no Rio de Janeiro, Brasil. Rev Bras Saúde Mater Infant. 2013; 13 (2): $89-100$

27. Santos-Neto ET, Oliveira AE, Zandonade E, Gama SGN, Leal MC. O que os cartões de pré-natal das gestantes revelam sobre a assistência nos serviços do SUS da Região Metropolitana da Grande Vitória, Espírito Santo, Brasil?. Cad Saúde Pública. 2012; 28 (9): 1650-62.

28. Pinho AA, França-Júnior I, Schraiber LB, D'Oliveira AFPL. Cobertura e motivos para a realização ou não do teste de Papanicolaou no município de São Paulo. Cad Saúde Pública. 2003; 19 (Supl. 2): 303-13. 